\title{
Taxa of Leafhoppers Carrying Phytoplasmas at Sites of Ash Yellows Occurrence in New York State
}

\author{
G. T. Hill and W. A. Sinclair, Department of Plant Pathology, Cornell University, Ithaca, NY 14853-4203
}

\begin{abstract}
Hill, G. T., and Sinclair, W. A. 2000. Taxa of leafhoppers carrying phytoplasmas at sites of ash yellows occurrence in New York State. Plant Dis. 84:134-138.

Leafhopper (Homoptera: Cicadellidae) populations were sampled and leafhopper carriers of ash yellows (AshY) phytoplasmas were identified as first steps toward vector identification. Nearly 5,000 leafhoppers were collected in malaise traps at two sites of high AshY incidence in New York state in 1996 and 1997. These insects comprised 33 taxa, including representatives of 13 genera known to contain phytoplasma vectors. The most abundant genus was Scaphoideus, with numbers about six times greater than any other genus. A total of 1,632 insects were assayed individually for phytoplasmas by polymerase chain reaction (PCR) amplification of phytoplasmal 16S rDNA and restriction fragment length polymorphism analyses of PCR products using restriction enzymes $T a q \mathrm{I}$ and $R s a \mathrm{I}$ separately. Phytoplasmas were detected in 35 insects, all but one in the subfamily Deltocephalinae. AshY phytoplasmas were detected in 19 of 812 individuals of Scaphoideus spp. and 1 of 87 of Colladonus clitellarius. Phytoplasmas of the Prunus Xdisease group were detected in 1 Scaphoideus sp., 4 individuals of C. clitellarius, and 4 of 83 Scaphytopius acutus individuals. Phytoplasmas of the aster yellows group were detected in 1 of 68 individuals of Gyponana spp. and 5 of S. acutus. AshY phytoplasma carriers merit testing for possible vector ability.
\end{abstract}

Most natural transmission of phytoplasmas occurs via phloem-feeding, homopteran insects, primarily leafhoppers (Cicadellidae). A few species of planthoppers (Cixiidae), psyllids (Psyllidae), and a froghopper (Cercopidae) are other known homopteran vectors $(5,18,22,34,37)$. Three stinkbugs in the genus Halyomorpha (Hemiptera: Pentatomidae) are the only reported phytoplasma vectors not in the Homoptera $(8,13)$. Phytoplasmas circulate and multiply within the bodies of their insect vectors. They can be transmitted into plants only after passing from the gut into the hemocoel and thence into salivary glands. Therefore, days to weeks elapse between phytoplasma acquisition and transmission to plants via the insect saliva $(16,26,34)$.

Ash yellows (AshY), a disease putatively caused by phytoplasmas, induces slow growth and premature decline of Fraxinus spp., notably $F$. americana L. (white ash). The symptoms, impact, and pathogen of AshY have been characterized $(11,32)$, but the insect vectors are not known. Although the leafhopper Para-

Corresponding author: G. T. Hill

E-mail: gth2@ cornell.edu

This research was supported by the McIntireStennis Cooperative Forestry Research Program.

Accepted for publication 23 September 1999.

Publication no. D-1999-1202-02R

(C) 2000 The American Phytopathological Society phlepsius irroratus (Say) and the froghopper Philaenus spumarius (L.) were reported to transmit naturally acquired phytoplasmas into ash test plants (20), the phytoplasmas were not identified, and laboratory colonies of these insect species failed to transmit AshY phytoplasmas (30).

Searches for vectors of phytoplasmas have been facilitated by molecular techniques, such as polymerase chain reaction (PCR), that have enabled the sensitive detection of phytoplasmal DNA in insects $(4,5,12,18,19,37)$. Although detection of phytoplasmas in an insect does not prove a vector relationship (35), the technique is useful for narrowing the search for potential vectors among many taxa. Knowledge of the vectors of AshY would enable a more complete understanding of the spread and distribution of the pathogen. Vector host and habitat preference, movement, and life cycle all have profound influence on the epidemiology of phytoplasmal diseases $(5,9)$. Objectives of this study were to examine the phenology of leafhopper populations on sites of AshY occurrence and to identify carriers of AshY phytoplasmas as first steps in vector identification.

\section{MATERIALS AND METHODS}

Insect collection. Insects were trapped on two sites of high AshY incidence near Ithaca, New York, in 1996 and 1997. Site 1 (elevation $305 \mathrm{~m}$ ) was a plantation of $F$. pennsylvanica Marsh. (green ash) in which trees were 7 years old in 1996. Over 50\% of the 720 trees present were known to have AshY (33). Ground cover was composed primarily of Asclepias syriaca L., Convolvulus arvensis L., Solidago rugosa Mill., and grasses. Site 2 (elevation $427 \mathrm{~m}$ ) was a small clearing in a dense stand of white ash saplings in the understory of a failed experimental plantation of Prunus serotina Ehrh. and Pinus strobus L. Other plants present included a Fragaria sp., Prunus virginiana L., Rhamnus cathartica L., Rubus allegheniensis Porter, S. rugosa, Viburnum dentatum L., and V. lentago L. AshY incidence on this site increased an average of $8 \%$ per year in 1991 to 1994 (31), and was estimated to be near $75 \%$ in 1996. The landscape surrounding both sites was a mixture of agricultural fields and forested plots. The distance between sites 1 and 2 was approximately $1.5 \mathrm{~km}$.

One 6-m malaise trap (3) with wet collection heads (John W. Hock Company, Gainesville, FL) was set up at each site. An A-frame support system (36) was used at site 1 due to lack of large trees to which the trap could be anchored. Trapped insects fell into mason jars containing $80 \%$ ethanol. Insects were harvested and clean ethanol-loaded jars installed every 2 to 5 days. Collections were sorted in ethanol, and leafhopper, planthopper, and froghopper taxa were saved. Ethanol-preserved and pinned voucher specimens of each taxon were retained. Specimens in $80 \%$ ethanol were stored at $-20^{\circ} \mathrm{C}$. Species were identified or their identities verified by C. H. Dietrich of the Illinois Natural History Survey, Champaign.

Assays for phytoplasmal DNA. Total nucleic acid was extracted from preserved insects using a protocol slightly modified from one devised by J. Zhang and S. A. Miller (Ohio Agricultural Research and Development Center, Wooster; personal communication). Ethanol was blotted from insects before the extraction procedure. Individual insects $<6 \mathrm{~mm}$ long were crushed and coarsely ground using a glass microcapillary tube in a 600- $\mu$ l Eppendorf tube containing $30 \mu \mathrm{l}$ of $\mathrm{NaOH}(0.5 \mathrm{~N})$ for approximately $30 \mathrm{~s}$. Then, $36 \mu \mathrm{l}$ of ice-cold Tris buffer (1.0 M, pH 8.0) was added. The suspension was centrifuged at 2,500 $\times g$ for $8 \mathrm{~min}$. The supernatant was transferred to a new tube, and $60 \mu \mathrm{l}$ of $70 \%$ ethanol $\left(-20^{\circ} \mathrm{C}\right)$ was added. After $1 \mathrm{~h}$ at $-20^{\circ} \mathrm{C}$, the suspension was centrifuged at 3,500 $\times g$ for $10 \mathrm{~min}$. The ethanol was decanted and the pellet dried at $65^{\circ} \mathrm{C}$. The pellet was resuspended in $60 \mu \mathrm{l}$ of Tris-EDTA (TE) buffer and stored at $4^{\circ} \mathrm{C}$. Reagent volumes 
were multiplied by 1.5 to accommodate insects $>6 \mathrm{~mm}$ long.

DNA was also extracted by the method of Dellaporta et al. $(6,11)$ from Catharanthus roseus (L.) G. Don plants singly infected with phytoplasma strains AshY1 (ash yellows group), CX (X-disease group), and NJAY (aster yellows group). The latter two strains, obtained from L. N. Chiykowski and T. A. Chen, respectively, were used as standards for comparison with field-detected phytoplasmas in PCRrestriction fragment length polymorphism (RFLP) analyses.

Nucleic acid samples extracted from individual insects were diluted 1:30 with sterile deionized water, and $1 \mu \mathrm{l}$ of dilute solution was used as template in each PCR mixture. Procedures and conditions for PCR were as described previously (11). Nucleic acids extracted from laboratoryreared Macrosteles quadrilineatus (Forbes) which had fed or not fed on aster yellows (AY)-phytoplasma-infected Callistephus chinensis (L.) Nees were used for positive and negative controls, respectively, in PCR. The phytoplasma-universal primer pairs P1/P7 (7,29) and R16F2/R2 (15) were used to prime the amplification of fragments of ribosomal DNA. Primer pair P1/P7 mediates the amplification of a 1.8kilobase $(\mathrm{kb})$ fragment containing nearly the entire 16S rRNA gene, the interspacer region, and a portion of the $5^{\prime}$ end of the 23S rRNA gene. Primer pair R16F2/R2 mediates amplification of a 1.24-kb fragment of the 16S rRNA gene internal to the P1/P7 priming sites. A 5- $\mu$ l sample of each reaction mixture obtained with primer set $\mathrm{P} 1 / \mathrm{P} 7$ was electrophoresed in a $0.7 \%$ agarose gel, and the amplimers were stained with ethidium bromide and visualized by UV transillumination. If an amplimer was observed, $2 \mu \mathrm{l}$ of the primary reaction mixture was diluted $1: 1,000$ with sterile deionized water, and $1 \mu \mathrm{l}$ of the diluted product was used as template in a second PCR using primer pair R16F2/R2. The second amplification was performed for two reasons. First, the primary amplification did not consistently yield enough DNA for phytoplasma differentiation by RFLP analysis. Second, it was desirable to use R16F2/R2 for identification purposes because published RFLP profiles of nine distinct phytoplasma groups $(14,15)$ were derived by analyses of R16F2/R2 amplimers. DNA from infected plant samples was diluted 1:10 with sterile deionized water, and phytoplasmal DNA was amplified using R16F2/R2. Amplimers were visualized as described above.

Amplimers obtained using R16F2/R2 were analyzed by restriction endonuclease digestion. Samples $(5 \mu \mathrm{l})$ of each PCR product were digested separately with $T a q \mathrm{I}$ and RsaI (GIBCO BRL, Grand Island, NY) according to the manufacturer's instructions. Digestion of $16 \mathrm{~S}$ rDNA of AshY phytoplasmas by TaqI yields an RFLP pattern unique to the AshY phytoplasma group (Group 16SrVII of Lee et al.; 14,15). Digestion by $R s a \mathrm{I}$ in conjunction with TaqI yields patterns that enable differentiation of phytoplasmas associated with AshY, AY (Group 16SrI), and Prunus X-disease (Group 16SrIII). Restriction fragments were separated by electrophoresis in a $2.5 \%$ agarose gel and were visualized as described above.

RFLP patterns obtained from R16F2/R2 amplimers were later verified via analyses

Table 1. Taxa and numbers of leafhoppers (Cicadellidae) collected at two sites of ash yellows incidence near Ithaca, New York, in 1996 and 1997 and detection of phytoplasmas in them

\begin{tabular}{|c|c|c|c|c|c|c|}
\hline \multirow[b]{2}{*}{ Leafhopper taxa } & \multicolumn{2}{|c|}{ Site 1} & \multicolumn{2}{|c|}{ Site 2} & \multirow[b]{2}{*}{ Proportion $^{\mathrm{a}}$} & \multirow[b]{2}{*}{ Identity, incidence $^{b}$} \\
\hline & 1996 & 1997 & 1996 & 1997 & & \\
\hline \multicolumn{7}{|l|}{ Aphrodinae } \\
\hline Aphrodes bicincta (Schrank) & 7 & 11 & 9 & 4 & $0 / 12$ & \\
\hline \multicolumn{7}{|l|}{ Coelidiinae } \\
\hline Jikradia olitoria (Say) & 35 & 25 & 28 & 18 & $0 / 46$ & \\
\hline \multicolumn{7}{|l|}{ Agalliinae } \\
\hline Agallia spp. & 26 & 14 & 9 & 12 & $\ldots$ & \\
\hline Agalliopsis spp. & 46 & 17 & 21 & 13 & $\ldots$ & \\
\hline \multicolumn{7}{|l|}{ Gyponinae } \\
\hline Gypona sp. & 3 & 2 & 4 & 0 & $\ldots$ & \\
\hline Gyponana scrupulosa (Spångberg) & 7 & 4 & 0 & 0 & $0 / 6$ & \\
\hline Gyponana spp. & 45 & 38 & 23 & 16 & $1 / 68$ & AY, 1 \\
\hline \multicolumn{7}{|l|}{ Cicadellinae } \\
\hline Draeculacephala spp. & 77 & 53 & 45 & 49 & $0 / 24$ & \\
\hline Graphocephala spp. & 104 & 68 & 49 & 25 & $0 / 24$ & \\
\hline Tylozygus bifidis (Say) & 27 & 14 & 16 & 19 & $0 / 24$ & \\
\hline \multicolumn{7}{|l|}{ Deltocephalinae } \\
\hline Allygus atomarius (Fabricius) & 33 & 28 & 0 & 4 & $0 / 36$ & \\
\hline Amblysellus curtisii (Fitch) & 26 & 31 & 19 & 6 & $\ldots$ & \\
\hline Anoscopus sp. & 13 & 19 & 16 & 22 & $\ldots$ & \\
\hline Athysanus argentarius (Metcalf) & 6 & 3 & 2 & 0 & $0 / 6$ & \\
\hline Chlorotettix tergatus (Fitch) & 17 & 6 & 9 & 11 & $0 / 12$ & \\
\hline Chlorotettix sp. & 15 & 15 & 11 & 7 & $0 / 18$ & \\
\hline Colladonus clitellarius (Say) & 55 & 61 & 8 & 3 & $5 / 87$ & AshY, $1 ;$ X-disease, 4 \\
\hline Endria inimica (Say) & 42 & 33 & 14 & 18 & $0 / 24$ & \\
\hline Fieberiella florii (Stål) & 6 & 10 & 14 & 4 & $0 / 20$ & \\
\hline Idiodonus kennicotti (Uhler) & 24 & 14 & 15 & 7 & $0 / 24$ & \\
\hline Macrosteles spp. & 120 & 99 & 78 & 52 & $0 / 60$ & \\
\hline Orientus ishidae (Matsumura) & 8 & 17 & 6 & 14 & $0 / 24$ & \\
\hline Osbornellus spp. ${ }^{\mathrm{c}}$ & 86 & 104 & 67 & 62 & $0 / 153$ & \\
\hline Paraphlepsius irroratus (Say) & 13 & 16 & 9 & 14 & $0 / 24$ & \\
\hline Paraphlepsius sp. & 5 & 4 & 6 & 3 & $\ldots$ & \\
\hline Prescottia lobata (Van Duzee) & 47 & 22 & 54 & 36 & $0 / 60$ & \\
\hline Scaphoideus intricatus Uhler & 14 & 7 & 11 & 9 & $1 / 34$ & AshY, 1 \\
\hline Scaphoideus spp. ${ }^{\mathrm{d}}$ & 699 & 546 & 491 & 359 & $19 / 778$ & AshY, $18 ;$ X-disease, 1 \\
\hline Scaphytopius acutus (Say) & 37 & 18 & 22 & 9 & $9 / 83$ & AY, $5 ;$ X-disease, 4 \\
\hline Other species & 54 & 25 & 61 & 35 & $\ldots$ & \\
\hline
\end{tabular}


of new PCR products obtained with primer pair P1/P7 from the original insect nucleic acid samples. This verification was made possible through the use of an optimized $\mathrm{P} 1 / \mathrm{P} 7$ protocol that became available after the bulk of the phytoplasmal DNA assays had been completed.

\section{RESULTS}

Insect collection. Approximately 5,000 leafhoppers were collected at the two sites. This collection comprised 33 taxa and included 13 genera in the subfamilies Aphrodinae, Gyponinae, and Deltocephalinae that contain known vectors of phytoplasmas (22): species of Aphrodes, Chlorotettix, Colladonus, Endria, Fieberiella, Gyponana, Idiodonus, Macrosteles, Orientus, Osbornellus, Paraphlepsius, Scaphoideus, and Scaphytopius (Table 1). More insects were trapped in 1996 than in 1997 at both sites, and more were trapped at site 1 than at site 2. Scaphoideus spp. were collected most frequently. Due to identification difficulties, however, only $S$. intricatus Uhler was identified prior to assay for phytoplasmal DNA. Six other species of Scaphoideus (S. densus Delong and Beery, $S$. elongatus Delong and Beery, S. minor Osborn, S. obtusus Osborn, and S. titanus Ball) were ultimately identified among preserved specimens. The most numerous leafhoppers after Scaphoideus spp. were Macrosteles spp. and Osbornellus spp., which were collected at less than $20 \%$ of the frequency of Scaphoideus. The peak of the Scaphoideus population was variable between site and year, occurring between 31 July and 19 September (Fig. 1). Collections of Gyponana spp., Osbornellus spp., and Prescottia lobata (Van Duzee) had apparent frequency distributions similar to that of Scaphoideus spp. One leafhopper, Jikradia olitoria, did not appear in the traps until early August, and its numbers peaked in early October. Numbers of Colladonus clitellarius (Say) peaked earlier (mid-July) than those of other taxa. This species was approximately 10 times more common at site 1 than site 2. Macrosteles spp. exhibited two peaks in population, one in late July and one in early September. Other leafhopper taxa had too few individuals to represent seasonal trends, or time-of-collection data were inadequate to suggest one. Gyponana scrupulosa (Spångberg) was the only leafhopper not collected at both sites.

Detection and identification of phytoplasmas. A total of 1,632 insects were assayed individually for phytoplasmas. Phytoplasmal DNA was detected in 35 leafhoppers, all but 1 in the subfamily Deltocephalinae. PCR products were obtained from $>95 \%$ of reaction mixtures using nucleic acid samples from $M$. quadrilineatus that had fed on AY-infected Callistephus chinensis and from all reaction mixtures using template DNA extracted from Catharanthus roseus in- fected with reference strains AshY1, CX, and NJAY. No phytoplasmal DNA was detected in $M$. quadrilineatus reared on healthy plants. Phytoplasmas of the AshY, AY, and Prunus X-disease groups were identified based on comparison of R16F2/R2 RFLP profiles (Fig. 2) to those of Lee et al. $(14,15)$ and to those of reference strains AshY1, CX, and NJAY.

The percentage of insects carrying phytoplasmas was less than $11 \%$ in each of the five insect taxa in which phytoplasmas were detected (Table 1). AshY phytoplasmas were detected in Scaphoideus intricatus, other Scaphoideus spp., and Colladonus clitellarius. Phytoplasmas of the Prunus X-disease group were detected in Scaphoideus sp., C. clitellarius, and Scaphytopius acutus. Phytoplasmas of the aster yellows group were detected in Gyponana sp. and S. acutus. Phytoplasmas were not detected in 58 specimens of Philaenus spumarius, a froghopper species previously implicated as a potential vector of AshY (20).

Phytoplasmas were detected in Scaphoideus spp. and other taxa throughout the collection period at both sites. There were no clear relationships among the year, time of collection, numbers collected, and the proportion of insects in which phytoplasmas were detected.

\section{DISCUSSION}

Leafhoppers containing phytoplasmas could be vectors, dead-end hosts, or nonhost carriers $(27,35)$. Overall, the proportion of insects in which phytoplasmas were detected was low, approximately $2 \%$ of those assayed. This proportion is consistent

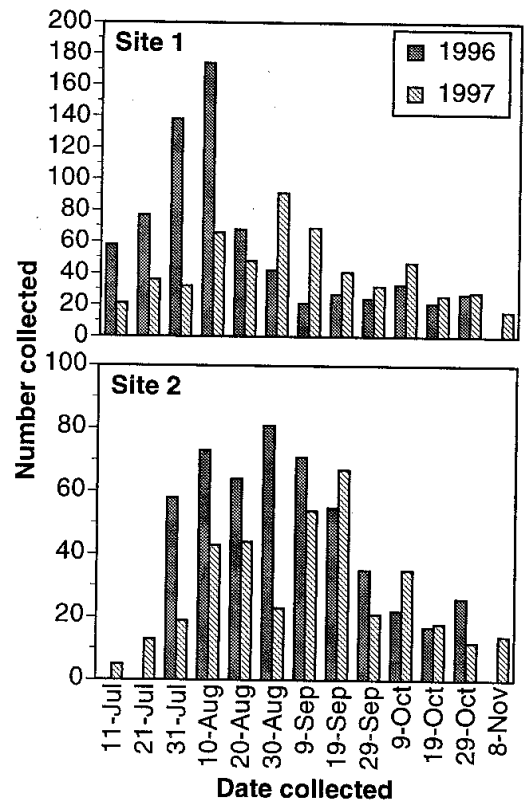

Fig. 1. Numbers of Scaphoideus spp. collected at two sites of ash yellows occurrence near Ithaca, New York, in 1996 and 1997. Dates are final days of respective collection periods. with findings from some other phytoplasmal systems. Mpunami et al. (21), in their search for vectors of coconut lethal disease in Tanzania, were able to amplify phytoplasmal rDNA from only 7 insects among more than 5,000 individuals tested. PoggiPollini et al. (24) detected phytoplasmas in only a small proportion of leafhoppers in their search for possible vectors of European stone fruit yellows. Davies and Eyre (5) found the proportion of the pear psyllid, Cacopsylla pyricola (Foerster), carrying pear decline phytoplasmas ranged from $<1 \%$ to near $40 \%$, depending on site characteristics and time of year.

The low frequency of phytoplasma carriers detected in this study may also be due to sensitivity of the detection technique used. Both the DNA extraction procedure and the use of only direct PCR for detection of phytoplasmal DNA presumably resulted in lower frequencies of detection than could have been obtained using more rigorous DNA extraction or nested PCR. The latter procedure has enabled extremely sensitive detection of phytoplasmas in both plants and insects $(4,12)$. We chose to pay attention only to those insects for which direct PCR products were observed, thus

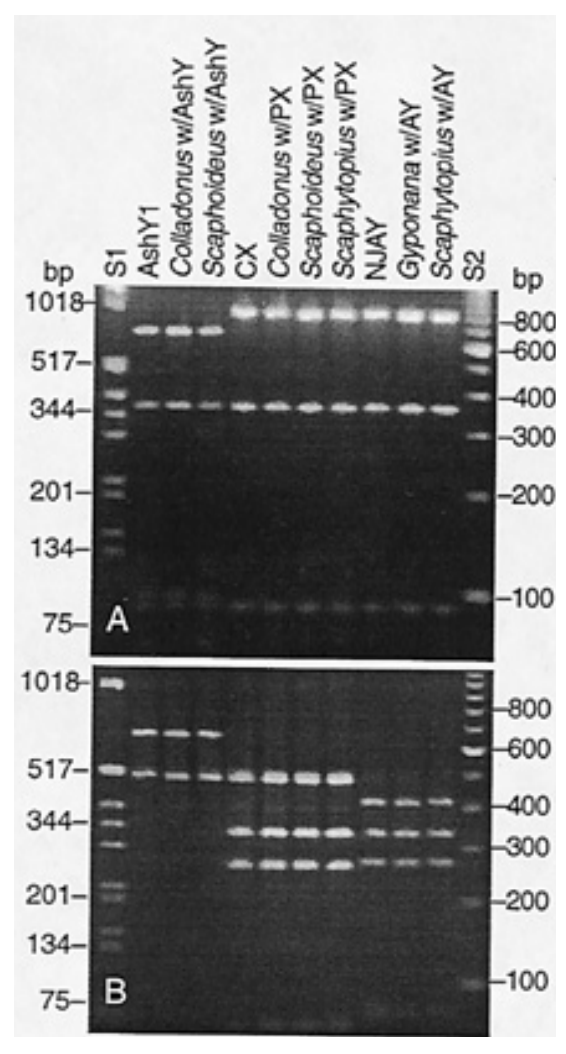

Fig. 2. Representative restriction fragment length polymorphism profiles, in $2.5 \%$ agarose, of polymerase chain reaction products amplified with primer pair R16F2/R2 from individual leafhoppers and phytoplasma reference strains AshY1, CX, and NJAY. (A) Products digested by TaqI. (B) Products digested by RsaI. S1 and S2 are 1-kilobase and 100-base pair ladders, respectively (GIBCO BRL, Grand Island, NY). Ash $\mathrm{Y}=$ ash yellows; $\mathrm{AY}=$ aster yellows; $\mathrm{PX}=$ Prunus X-disease. 
arbitrarily disregarding insects that may have harbored low or nascent populations of phytoplasmas detectable with nested PCR. The rationale for this approach was that it is biased toward detection of phytoplasmal populations that have increased to high titer within their carriers.

Seasonal population trends could be discerned for several of the most numerous leafhopper groups in the collections. These groups exhibited single population peaks between late July and early September, perhaps indicating a single generation per year. Their numbers diminished greatly before the first frosts in autumn. The delay in population peaks of Scaphoideus spp. and other taxa at site 2 was likely due to more shade and lower temperature, because the site was at higher elevation and was wooded. Only Macrosteles spp. exhibited a seasonal population trend that indicated multiple generations. The seasonal trends observed may have been verified or extended if we had begun collecting in late spring. Our July starting dates reflected the desire to collect insects during the period in which phytoplasma acquisition from leaves would likely be most frequent.

The insect collection method facilitated the trapping of a large number of airborne adult leafhoppers. Insects and their DNA were preserved immediately upon falling into the ethanol (25). This method also allowed collection of taxa potentially moving between ash trees or from groundcover plants to and from ash. Leafhopper taxa obtained with a sweep net directly from ash (data not shown) or collected previously from sticky traps exposed at sites of AshY incidence near Ithaca (W. A. Sinclair, unpublished) were among those found in the malaise-trap collections.

Scaphoideus spp., in addition to being the largest group of leafhoppers collected, also yielded the most samples testing positive for phytoplasmal DNA, almost entirely that of AshY phytoplasmas. Barnett (2) indicated that Scaphoideus spp. are not common and that large collections are not usually made. Therefore, little research has been completed on the host or plant relationships of this genus. Identification of the Scaphoideus genus is problematic. Its taxonomy is based primarily on morphology of male genitalia, making identification of females and nymphs difficult using available keys such as that by Barnett (2). In our study, females were collected most frequently, often with no associated males that appeared to be of the same species. As a further complication, intraspecific variability in genital characters of males may cause uncertainty in identification (2).

The genus Scaphoideus contains vectors of several other phytoplasmal pathogens of woody plants. $S$. titanus transmits the causal agent of flavescence dorée, a serious disease of grapevines in Europe. In New York, S. titanus was implicated as a poten- tial vector of grapevine yellows (17). $S$. luteolus Van Duzee is a vector of elm yellows (1). S. carinatus Osborn and S. diutius DeLong and Mohr were shown to transmit the phytoplasma associated with $\mathrm{X}$-disease of stone-fruit trees $(23,28)$. Additional vector relationships of Scaphoideus spp. and tree-infecting phytoplasmas will likely be elucidated if the difficulty and uncertainty of identifying these insects is reduced. Only one Scaphoideus species, S. obtusus, has been reported as collected from Fraxinus spp. (2). It is probable that $S$. intricatus and other Scaphoideus spp. in which AshY phytoplasmas were detected had fed on ash, because it was the dominant plant at each site and because AshY phytoplasmas have not been detected in searches of other plant species on sites of high AshY incidence (10).

One individual of Colladonus clitellarius carrying AshY phytoplasmas was identified. This species is a known vector of eastern X-disease of peach (22). Perhaps it may harbor or transmit more than one type of phytoplasma. Precedents for one species serving as a host for more than one phytoplasma exist. For example, C. montanus (Van Duzee) and Fieberiella florii both transmit western X-disease and aster yellows phytoplasmas (22). Detection of AshY phytoplasmas in $C$. clitellarius, $S$. intricatus, and other Scaphoideus spp. indicates that insects in these taxa should be tested for AshY vector ability.

\section{ACKNOWLEDGMENTS}

We thank H. M. Griffiths for technical assistance and valuable discussions; C. M. Henzler for technical help; C. H. Dietrich for identifying leafhoppers; W. E. Styer for providing Macrosteles quadrilineatus; L. Chiykowski and T. A. Chen for phytoplasma strains; J. Zhang and S. A. Miller for communicating their protocol for DNA extraction from leafhoppers; and A. Hajek, G. W. Hudler, T. C. Harrington, and an anonymous reviewer for helpful comments about the manuscript.

\section{LITERATURE CITED}

1. Baker, W. L. 1948. Transmission by leafhoppers of the virus causing phloem necrosis of American elm. Science 108:307-308.

2. Barnett, D. E. 1976. A revision of the nearctic species of the genus Scaphoideus (Homoptera: Cicadellidae). Trans. Am. Entomol. Soc. 102:485-593.

3. Butler, G. D. 1966. An insect flight trap for crop areas. J. Econ. Entomol. 30:1030-1031.

4. Danielli, A., Bertaccini, A., Vibio, M., Mori, N., Murari, E., Posenato, G., and Girolami, V. 1996. Detection and molecular characterization of phytoplasmas in the planthopper Metcalfa pruinosa (Say) (Homoptera: Flatidae). Phytopathol. Mediterr. 35:62-65.

5. Davies, D. L., and Eyre, S. 1996. Detection of phytoplasmas associated with pear decline in pear psyllids by polymerase chain reaction. Pages 67-72 in: Brighton Crop Prot. Conf. Symp. Proc. No 65: Diagnostics in Crop Production. F. M. McKim, ed. British Crop Protection Council, Surrey, UK.

6. Dellaporta, S. L., Wood, J., and Hicks, J. B. 1983. A plant DNA minipreparation: Version II. Plant Mol. Biol. Rep. 1:19-21.

7. Deng, S., and Hiruki, C. 1991. Amplification of $16 \mathrm{~S}$ rRNA genes from culturable and non- culturable Mollicutes. J. Microbiol. Methods 14:53-61.

8. Doi, Y., and Asuyama, H. 1981. Paulownia witches' broom disease. Pages 135-145 in: Mycoplasma Diseases of Trees and Shrubs. K. Maramorosch and S. P. Raychaudhuri, eds. Academic Press, New York.

9. Gold, R. E. 1979. Leafhopper vectors and western X-disease. Pages 587-602 in: Leafhopper Vectors and Plant Disease Agents. K. Maramorosch and K. F. Harris, eds. Academic Press, New York.

10. Griffiths, H. M., Gundersen, D. E., Sinclair, W. A., Lee, I.-M., and Davis, R. E. 1994. Mycoplasmalike organisms from milkweed, goldenrod, and spirea represent two new 16S rRNA subgroups and three new strain subclusters related to peach X-disease MLOs. Can. J. Plant Pathol. 16:255-260.

11. Griffiths, H. M., Sinclair, W. A., Smart, C. M., and Davis, R. E. 1999. The phytoplasma associated with ash yellows and lilac witches'broom: 'Candidatus Phytoplasma fraxini.' Int. J. Syst. Bacteriol. 49:1605-1614.

12. Gundersen, D. E., and Lee, I.-M. 1996. Ultrasensitive detection of phytoplasmas by nested-PCR assays using two universal primer pairs. Phytopathol. Mediterr. 35:144-151.

13. Hiruki, C. 1998. Recent advances in paulownia witches'-broom research (Abstr.). Eur. J. For. Pathol. 28:81.

14. Lee, I-M., Gundersen-Rindal, D. E., Davis, R. E., and Bartoszyk, I. M. 1998. Revised classification scheme of phytoplasmas based on RFLP analyses of 16S rRNA and ribosomal protein gene sequences. Int. J. Syst. Bacteriol. 48:1153-1169.

15. Lee, I.-M., Hammond, R. W., Davis, R. E., and Gundersen, D. E. 1993. Universal amplification and analysis of pathogen $16 \mathrm{~S}$ rDNA for classification and identification of mycoplasmalike organisms. Phytopathology 83:834-842.

16. Lefol, C., Lherminier, J., Boudon-Padieu, E. Larrue, J., Louis, C., and Caudwell, A. 1994. Propagation of flavescence dorée MLO (mycoplasma-like organism) in the leafhopper vector Euscelidius variegatus $\mathrm{Kbm}$. J. Invertebr. Pathol. 63:285-293.

17. Maixner, M., Pearson, R. C., Boudon-Padieu, E., and Caudwell, A. 1993. Scaphoideus titanus, a possible vector of grapevine yellows in New York. Plant Dis. 77:408-413.

18. Marcone, C., Ragozzino, A., Firrao, G., and Locci, R. 1994. Detection of a Rubus stunt isolate and characterization by RFLP analysis. Riv. Patol. Veg. S. V. 4:47-58.

19. Marzachi, C., Veratti, F., and Bosco, D. 1998 Direct PCR detection of phytoplasmas in experimentally infected insects. Ann. Appl. Biol. 133:45-54.

20. Matteoni, J. A., and Sinclair, W. A. 1988. Elm yellows and ash yellows. Pages 19-31 in: Tree Mycoplasmas and Mycoplasma Diseases. C. Hiruki, ed. University of Alberta, Edmonton, Canada.

21. Mpunami, A., Jones, P., Tymon, A., and Dickinson, M. 1996. The use of DNA probes and PCR for detection of coconut lethal disease (LD) in Tanzania. Brighton Crop Prot. Conf. Pests \& Dis. 2:18-21.

22. Nielson, M. W. 1979. Taxonomic relationships of leafhopper vectors of plant pathogens. Pages 3-27 in: Leafhopper Vectors and Plant Disease Agents. K. Maramorosch and K. F. Harris, eds. Academic Press, New York.

23. Nielson, M. W. 1985. Leafhopper systematics. Pages 11-39 in: The Leafhoppers and Plant hoppers. L. R. Nault and J. G. Rodriguez, eds. Wiley, New York.

24. Poggi-Pollini, C., Giunchedi, L., Bussani, R., Mordenti, G. L., Nicoli, A. R., and Cravedi, P. 1997. Early results of work on the vectors of 
European stone fruit yellows. Bull. OILB/SROP 20:39-42.

25. Post, R. J., Flook, P. K., and Millest, A. L. 1993. Methods for the preservation of insects for DNA studies. Biochem. Syst. Ecol. 21:8592.

26. Purcell, A. H., and Nault, L. R. 1991. Interactions among plant pathogenic prokaryotes, plants, and insect vectors. Pages 383-405 in: Microbial Mediation of Plant-Herbivore Interactions. P. Barbosa, V. A. Krischik, and C. G. Jones, eds. Wiley, New York.

27. Purcell, A. H., Richardson, J., and Finlay, A. 1981. Multiplication of the agent of X-disease in a non-vector leafhopper Macrosteles fascifrons. Ann. Appl. Biol. 99:283-289.

28. Rosenberger, D. A., and Jones, A. L. 1978. Leafhopper vectors of the peach X-disease pathogen and its seasonal transmission from chokecherry. Phytopathology 68:782-790.

29. Schneider, B., Seemüller, E., Smart, C. D., and Kirkpatrick, B. C. 1995. Phylogenetic classification of plant pathogenic mycoplasma-like organisms or phytoplasmas. Pages 369-380 in: Molecular and Diagnostic Procedures in Mycoplasmology. Vol. 1. S. Razin and J. G. Tully, eds. Academic Press, San Diego, CA.

30. Sinclair, W. A., and Griffiths, H. M. 1994. Ash yellows and its relationship to dieback and decline of ash. Annu. Rev. Phytopathol. 32:49-60.

31. Sinclair, W. A., and Griffiths, H. M. 1995. Epidemiology of a slow-decline phytoplasmal disease: ash yellows on old-field sites in New York State. Phytopathology 85:123-128.

32. Sinclair, W. A., Griffiths, H. M., and Davis, R. E. 1996. Ash yellows and lilac witches'broom: phytoplasmal diseases of concern in forestry and horticulture. Plant Dis. 80:468475 .

33. Sinclair, W. A., Whitlow, T. H., and Griffiths, H. M. 1997. Heritable tolerance of ash yellows phytoplasmas in green ash. Can. J. For.
Res. 27:1928-1935.

34. Tsai, J. H. 1979. Vector transmission of mycoplasmal agents of plant diseases. Page 265-307 in: The Mycoplasmas. Vol. III Plant and Insect Mycoplasmas. R. F. Whitcomb and J. G. Tully, eds. Academic Press, New York.

35. Vega, F. E., Davis, R. E., Barbosa, P., Dally, E. L., Purcell, A. H., and Lee, I.-M. 1993. Detection of a plant pathogen in a nonvector insect species by the polymerase chain reaction. Phytopathology 83:621-624.

36. Walker, T. J. 1978. Migration and re-migration of butterflies through peninsular Florida: quantification with malaise traps. J. Lepid. Soc. 32:178-190.

37. Weber, A., and Maixner, M. 1998. Survey of populations of the planthopper Hyalesthes $o b$ soletus Sign. (Auchenorrhyncha: Cixiidae) for infection with the phytoplasma causing gravevine yellows in Germany. J. Appl. Entomol. 122:375-381. 